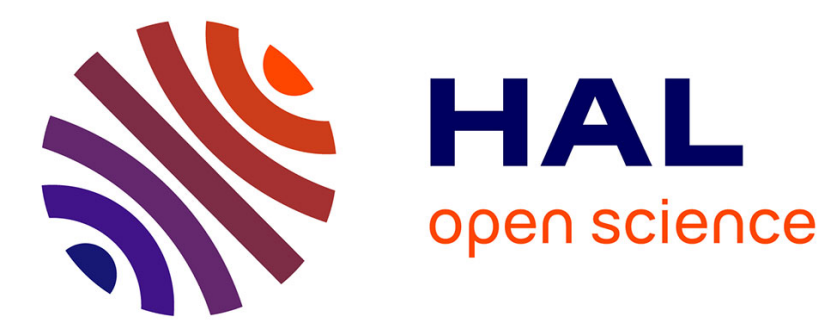

\title{
FDI, banking crises and growth: direct and spill over effects
}

\author{
Brahim Gaies, Stéphane Goutte, Khaled Guesmi
}

\section{To cite this version:}

Brahim Gaies, Stéphane Goutte, Khaled Guesmi. FDI, banking crises and growth: direct and spill over effects. 2019. halshs-01967999

\section{HAL Id: halshs-01967999 \\ https://shs.hal.science/halshs-01967999}

Preprint submitted on 9 Jan 2019

HAL is a multi-disciplinary open access archive for the deposit and dissemination of scientific research documents, whether they are published or not. The documents may come from teaching and research institutions in France or abroad, or from public or private research centers.
L'archive ouverte pluridisciplinaire HAL, est destinée au dépôt et à la diffusion de documents scientifiques de niveau recherche, publiés ou non, émanant des établissements d'enseignement et de recherche français ou étrangers, des laboratoires publics ou privés. 


\title{
FDI, banking crises and growth: direct and spill over effects
}

\author{
Brahim GAIES \\ IPAG Business School, Paris, France \\ Stéphane GOUTTE \\ University Paris 8, France \\ Paris School of Business, Paris, France \\ Khaled GUESMI \\ IPAG Business School, Paris, France \\ Telfer School of Management, University of Ottawa, Canada
}

\begin{abstract}
This study suggests a new decomposition of the effect of foreign direct investment (FDI) on the long-term growth of developing countries. It reveals that FDI not only has a direct positive effect on growth, but also increases it by reducing the recessionary effect resulting from a banking crisis. However, these advantages are conditioned by the FDI threshold, which in turn depends on the "absorption capacity" of the host country.
\end{abstract}

JEL: F65, F36, G01, G15

Keywords: growth; FDI; system GMM; panel logit model 


\section{Introduction}

Since the mid-1980s, the march towards financial globalization in developing countries has been based on FDI flows which have outpaced portfolio investment and debt flows (Kusek and Silva, 2017). Recognizing that FDI is central to the phenomenon of financial globalization, recent studies focus on how FDI impacts economic growth in developing countries. Overall, they evidence that the spill over benefits of FDI outweigh their direct advantages. More specifically, FDI can increase growth in developing countries by promoting institutional quality (Okada, 2013); ensuring technology transfer (Neto and Veiga, 2013); developing the domestic financial sector (Kunieda, Okada and Shibata, 2014; Ahmed, 2016; Trabelsi and Cherif, 2017); and improving human capital quality (Iamsiraroj, 2016).

Regarding this literature, the main novelty of this study is that it presents a new decomposition of the effect (direct and spill over) of FDI on growth, considering its interaction with banking crises in 67 developing countries among low and lower-middle income countries, according to the World Bank classification, between 1972 and 2011.

\section{Methodology}

\section{i) Baseline estimates}

To decompose the effect of FDI on economic growth, we specify two growth models.

$$
\begin{aligned}
& \text { GDPPCG }_{i t}=\alpha_{0}+\gamma \text { GDPPC }_{i t-1}+\alpha_{1} F D I_{i t}+\alpha_{2} C R I S I S++\beta X_{i t}+\mu_{i}+\lambda_{t}+\varepsilon_{i t} \\
& G D P P C G_{i t}=\alpha_{0}+\gamma \text { GDPPC }_{i t-1}+\alpha_{l} F_{i t}+\alpha_{2} \text { CRISIS }+\alpha_{3}\left(F D I_{i t} \mathrm{x} C R I S I S\right)+\beta X_{i t}+\mu_{i}+\lambda_{t}+\varepsilon_{i t}
\end{aligned}
$$

GDPPCG represents the dependent variable, namely real GDP per capita growth. FDI is the first interest variable. It is measured by the total stocks of FDI assets and liabilities to GDP (FDIT) or the stocks of FDI liabilities to GDP (FDIL), extracted from the External Wealth of Nations Dataset. CRISIS is the second interest variable. It is taken from the Systemic Banking Crises Database. It equals "one" if there is a banking crisis in country $i$ in year $t$, and "zero" otherwise. The control variables are the lagged real GDP per capita and X, which is a matrix regrouping the sum of exports and imports to GDP (TRADE); terms-of-trade growth (TERM); government spending to GDP (GOV); and secondary school enrolment (EDU). These variables are obtained from the World Bank Indicators database (WDI). $\alpha_{0}$ is a constant; $\mu_{i}$ is the countryspecific effect; $\lambda_{t}$ is the time-specific effect; and $\varepsilon_{i t}$ is the error term. To estimate these growth models (see below, Table 1, columns 1 to 4) and address endogeneity bias (Roodman, 2009), we utilize the GMM system dynamic panel data estimator (Two-step system GMM) developed by Arellano and Boyer (1995) and Blundell and Bond (1998), and we compute robust two-step standard errors by following the methodology proposed by Newey and Windmeijer (2009).

\section{ii) Robustness tests}

In order to examine the sensitivity of the spill over effect of FDI on growth through crises, we first reconduct our baseline estimates by controlling for the domestic banking credit (\% of GDP) (CREDIT, from WDI) in Equation (2) (see below, Table 1, columns 5 and 6). Second, we augment Equation (2) with the squared values of FDIT and FDIL to examine the potential FDI threshold effects (see below, Table 1, columns 7 and 8). Third, we run a regression of a banking crisis model using the logit panel model (conditional fixed-effects). The model explains CRISIS by FDI variables (squared and in level) as well as a set of control variables. These are GDPPC, GOV, the GDP growth (GROWTH), the growth of money and quasi money to total reserves 
ratio (M2toRES), the growth of claims on private sector to GDP (CLAIM-PRIV), the domestic credit to private sector (\% of GDP) (CPRIVET) and the inflation rate (INF), extracted from WDI, as well as POLI, which is the indicator of political rights $(1=$ most free and $7=$ least free $)$ obtained from the Freedom House database (see Table 2 below).

\section{Results and interpretations}

Table 1 below shows that the coefficients of the variables FDIT and FDIL are significant at the $5 \%$ level and positive; and those of CRISIS are significant at the $1 \%$ and $5 \%$ level and negative in all regressions. It highlights that FDI has a positive direct effect on growth. Conversely, banking crises are hindering it. In addition, the coefficients of the interaction terms FDIT $x$ CRISIS and FDIL $x$ CRISIS are significant and positive in all regressions. This result indicates that FDI also permits a spill over (indirect) benefit on growth in developing countries. It consists in decreasing the recessionary effect resulting from a banking crisis. However, when we control for the domestic banking credit (columns 5 and 6), the statistical significance of the interaction terms decreases from $1 \%$ to $10 \%$. This could be explained by the negative effect of the crisis on credit, which could reduce the spill over benefit of FDI. Also, when we augment Equation (2) with the squared values of the FDI variables (columns 7 and 8), they take negative coefficients at the $10 \%$ significance level. It seems that above a critical threshold, the effect of FDI on growth could become negative. This effect could be explained by the limitation of the host country's "absorption capacity" (Durham, 2004). Furthermore, on the basis of the positivity and significance of the coefficients of the TRADE variable at $1 \%$ and 5\%, it appears that trade openness is one of the drivers of economic growth in developing countries. Besides, the outputs of Table 2 strongly consolidate this result. Indeed, the negativity and significance of the marginal effect of FDIT and FDIL on CRISIS in all regressions evidence that FDI is a negative determinant of banking crises occurrence. Although, the non-significance of the marginal effect of the squared values of these variables indicates that above a critical threshold, FDI may no longer play this positive role.

In sum, these direct and spill over advantages can theoretically be explained by two mechanisms. First, FDI reduces the negative effect of banking crises because it promotes supervision and risk managing in the domestic financial markets through the presence of foreign investors, which indirectly oblige the local institutions to improve the quality of their governance out of fear of a "sudden stop". Second, foreign investors enhance liquidity and technology transfer, which catalyse the domestic industry and foreign trade. The latter, as well as domestic investment, which increases through FDI due to their complementarity (crowding effect), are the main engines of growth. However, despite these positive effects, above a critical threshold, FDI could undermine expansion because of the non-validation of certain conditions related to the financial and institutional development in developing countries (Durham, 2004). 
Table 1. Growth Models

\begin{tabular}{|c|c|c|c|c|c|c|c|c|}
\hline \multirow{2}{*}{$\begin{array}{l}\text { Estimates } \\
\text { Columns }\end{array}$} & \multicolumn{4}{|c|}{ Baseline } & \multicolumn{4}{|c|}{ Robustness } \\
\hline & 1 & 2 & 3 & 4 & 5 & 6 & 7 & 8 \\
\hline L.GDPPC & $\begin{array}{c}-0.033 \\
(0.021)\end{array}$ & $\begin{array}{c}-0.033 * \\
(0.018)\end{array}$ & $\begin{array}{c}-0.031 \\
(0.023)\end{array}$ & $\begin{array}{l}-0.031 \\
(0.019)\end{array}$ & $\begin{array}{c}-0.014 \\
(0.012)\end{array}$ & $\begin{array}{l}-0.012 \\
(0.012)\end{array}$ & $\begin{array}{c}-0.040 * * \\
(0.017)\end{array}$ & $\begin{array}{l}-0.041 * \\
(0.021)\end{array}$ \\
\hline FDIT & $\begin{array}{c}\mathbf{0 . 0 4 9} * * \\
(0.023)\end{array}$ & $\begin{array}{c}\mathbf{0 . 0 4 0} * * * \\
(0.020)\end{array}$ & & & $\begin{array}{c}\mathbf{0 . 0 5 5}^{* * *} \\
(0.021)\end{array}$ & & $\begin{array}{c}\mathbf{0 . 0 8 0} * * * \\
(0.028)\end{array}$ & \\
\hline FDIL & & & $\begin{array}{c}\mathbf{0 . 0 5 0} * * \\
(0.022)\end{array}$ & $\begin{array}{c}\mathbf{0 . 0 4 1} * * \\
(0.019)\end{array}$ & & $\begin{array}{c}\mathbf{0 . 0 5 7} * * \\
(0.024)\end{array}$ & & $\begin{array}{c}\mathbf{0 . 0 6 6 * *} \\
(0.026)\end{array}$ \\
\hline FDIT $^{2}$ & & & & & & & $\begin{array}{c}-\mathbf{0 . 1 3 2} * \\
(0.067)\end{array}$ & \\
\hline FDIL $^{2}$ & & & & & & & & $\begin{array}{c}\mathbf{- 0 . 1 0 2} * \\
(0.054)\end{array}$ \\
\hline CRISIS & $\begin{array}{c}-\mathbf{0 . 0 2 7} * * \\
(0.013)\end{array}$ & $\begin{array}{c}-\mathbf{- 0 . 0 4 2} * * * \\
(0.014)\end{array}$ & $\begin{array}{c}-\mathbf{0 . 0 2 7} * * \\
(0.013)\end{array}$ & $\begin{array}{c}-\mathbf{- 0 . 0 4 3} * * * * \\
(0.012)\end{array}$ & $\begin{array}{c}-\mathbf{- 0 . 0 3 9} * * \\
(0.016)\end{array}$ & $\begin{array}{c}-\mathbf{- 0 . 0 4 0} * * \\
(0.015)\end{array}$ & $\begin{array}{c}-\mathbf{- 0 . 0 3 8} * * * * \\
(0.014)\end{array}$ & $\begin{array}{c}-\mathbf{0 . 0 3 6} * * * * \\
(0.012)\end{array}$ \\
\hline FDIT X CRISIS & & $\begin{array}{c}\mathbf{0 . 1 1 3} * * * * \\
(0.040)\end{array}$ & & & $\begin{array}{l}\mathbf{0 . 1 2 8}^{*} \\
(0.072)\end{array}$ & & $\begin{array}{c}\mathbf{0 . 1 3 1} * * * * \\
(0.045)\end{array}$ & \\
\hline FDIL X CRISIS & & & & $\begin{array}{c}\mathbf{0 . 1 2 2} * * * * \\
(0.042)\end{array}$ & & $\begin{array}{l}\text { 0.150* } \\
(0.089)\end{array}$ & & $\begin{array}{c}\mathbf{0 . 1 2 9} * * * \\
(0.040)\end{array}$ \\
\hline TRADE & $\begin{array}{c}0.040 * * * \\
(0.012)\end{array}$ & $\begin{array}{c}0.041 * * * \\
(0.012)\end{array}$ & $\begin{array}{c}0.037 * * * \\
(0.014)\end{array}$ & $\begin{array}{c}0.039 * * * \\
(0.013)\end{array}$ & $\begin{array}{c}0.029 * * * \\
(0.009)\end{array}$ & $\begin{array}{c}0.029 * * * \\
(0.009)\end{array}$ & $\begin{array}{c}0.033 * * * \\
(0.011)\end{array}$ & $\begin{array}{c}0.034 * * \\
(0.014)\end{array}$ \\
\hline EDU & $\begin{array}{c}0.016 \\
(0.011)\end{array}$ & $\begin{array}{c}0.014 \\
(0.011)\end{array}$ & $\begin{array}{c}0.017 \\
(0.012)\end{array}$ & $\begin{array}{c}0.013 \\
(0.012)\end{array}$ & $\begin{array}{c}0.007 \\
(0.007)\end{array}$ & $\begin{array}{c}0.005 \\
(0.007)\end{array}$ & $\begin{array}{c}0.021 * * \\
(0.010)\end{array}$ & $\begin{array}{c}0.024 * * \\
(0.011)\end{array}$ \\
\hline TERM & $\begin{array}{l}-0.000 \\
(0.018)\end{array}$ & $\begin{array}{l}-0.000 \\
(0.014)\end{array}$ & $\begin{array}{c}0.001 \\
(0.018)\end{array}$ & $\begin{array}{c}0.001 \\
(0.014)\end{array}$ & $\begin{array}{c}-0.008 \\
(0.016)\end{array}$ & $\begin{array}{l}-0.011 \\
(0.015)\end{array}$ & $\begin{array}{c}0.015 \\
(0.015)\end{array}$ & $\begin{array}{c}0.008 \\
(0.022)\end{array}$ \\
\hline GOV & -0.014 & -0.012 & -0.016 & -0.013 & $\begin{array}{c}-0.025^{*} \\
(0.013)\end{array}$ & $\begin{array}{l}-0.022 \\
(0.014)\end{array}$ & $\begin{array}{l}-0.010 \\
(0.014)\end{array}$ & $\begin{array}{l}-0.011 \\
(0.014)\end{array}$ \\
\hline CREDIT & $(0.018)$ & $(0.015)$ & $(0.018)$ & $(0.0$ & $\begin{array}{c}0.004 \\
(0.008)\end{array}$ & $\begin{array}{c}0.003 \\
(0.008)\end{array}$ & & \\
\hline Constant & $\begin{array}{c}0.037 \\
(0.122)\end{array}$ & $\begin{array}{c}0.034 \\
(0.105)\end{array}$ & $\begin{array}{c}0.038 \\
(0.130)\end{array}$ & $\begin{array}{c}0.033 \\
(0.111)\end{array}$ & $\begin{array}{c}0.043 \\
(0.096)\end{array}$ & $\begin{array}{c}0.045 \\
(0.092)\end{array}$ & $\begin{array}{c}0.014 \\
(0.104)\end{array}$ & $\begin{array}{c}0.043 \\
(0.084)\end{array}$ \\
\hline Observations & 289 & 289 & 289 & 289 & 289 & 289 & 289 & 289 \\
\hline AR2 P-value & 0.178 & 0.139 & 0.186 & 0.138 & 0.505 & 0.557 & 0.212 & 0.252 \\
\hline Hansen P-value & 0.466 & 0.616 & 0.436 & 0.585 & 0.475 & 0.405 & 0.455 & 0.658 \\
\hline
\end{tabular}

Non-overlapping five-year data. Standard errors are presented below the corresponding coefficient. Symbols *,** and *** mean significant at $10 \%, 5 \%$ and $1 \%$, respectively.

Table 2. Baking Crisis Model

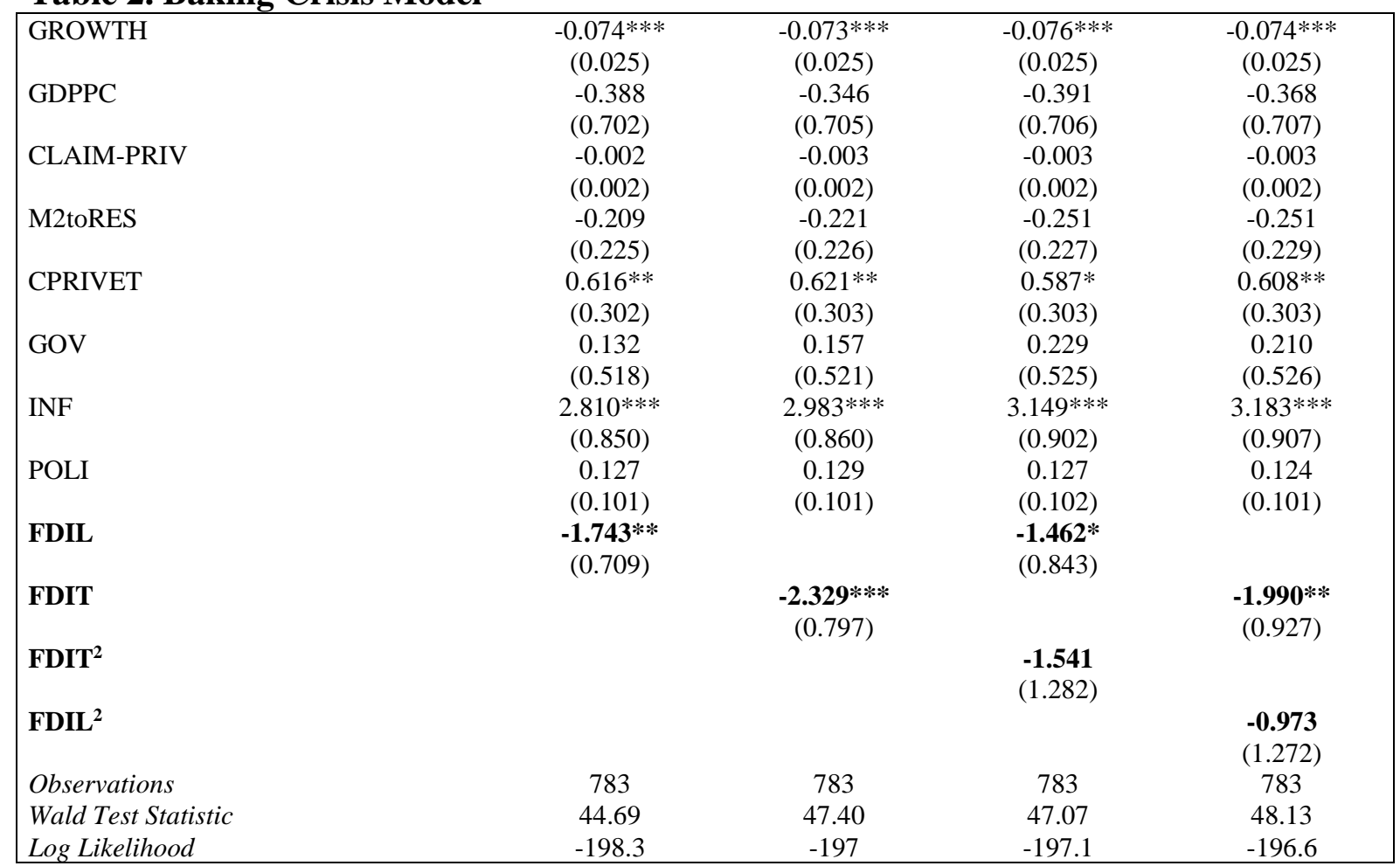

Yearly data. Standard errors are presented below the corresponding coefficient. Marginal effects and the coefficients of the constant are reported. Symbols *,** and $* * *$ indicate statistical significance at $10 \%, 5 \%$, and $1 \%$, respectively. 


\section{Conclusions}

This study shows that FDI not only has a direct positive effect on long-term growth in developing countries, but also increases it by reducing the recessionary effect resulting from a banking crisis. However, beyond a critical threshold, FDI could no longer play this positive role, as it remains dependent on the "absorption capacity" of the host country, in terms of financial and institutional development. Accordingly, it is recommended that policymakers open up to FDI while closely monitoring its expansion. A regional analysis could be considered to further develop these results.

\section{References}

Ahmed, A. D. (2016). Integration of financial markets, financial development and growth: Is Africa different?. Journal of International Financial Markets, Institutions and Money, 42, 43-59.

Arellano, M., \& Bover, O. (1995). Another look at the instrumental variable estimation of errorcomponents models. Journal of Econometrics, 68(1), 29-51.

Blundell, R., \& Bond, S. (1998). Initial conditions and moment restrictions in dynamic panel data models. Journal of Econometrics, 87(1), 115-143.

Durham, J. B. (2004). Absorptive capacity and the effects of foreign direct investment and equity foreign portfolio investment on economic growth. European economic review, $48(2), 285-306$

Iamsiraroj, S. (2016). The foreign direct investment-economic growth nexus. International Review of Economics \& Finance, 42(C), 116-133.

Kunieda, T., Okada, K., \& Shibata, A. (2014). Corruption, capital account liberalization, and economic growth: Theory and evidence. International Economics, 139, 80-108.

Kusek, P., \& Silva, A. (2017). What Matters to Investors in Developing Countries: Findings from the Global Investment Competitiveness Survey. Global Investment Competitiveness Report 2017/2018, 19.

Lensink, R., \& Morrissey, O. (2006). Foreign direct investment: Flows, volatility, and the impact on growth. Review of International Economics, 14(3), 478-493.

Neto, D. G., \& Veiga, F. J. (2013). Financial globalization, convergence and growth: The role of foreign direct investment. Journal of International Money and Finance, 37(C), 161186.

Newey, W. K., \& Windmeijer, F. (2009). Generalized method of moments with many weak moment conditions. Econometrica, 77(3), 687-719.

Okada, K. (2013). The interaction effects of financial openness and institutions on international capital flows. Journal of Macroeconomics, 35(C), 131-143.

Reisen, H., \& Soto, M. (2001). Which Types of Capital Inflows Foster Developing-Country Growth?. International Finance, 4(1), 1-14.

Roodman, D. (2009). How to do xtabond2: An introduction to difference and system GMM in Stata. Stata Journal, 9(1), 86136.

Trabelsi, M., \& Cherif, M. (2017). Capital account liberalization and financial deepening: Does the private sector matter?. The Quarterly Review of Economics and Finance, 64(C), 141151.

1995 words 